\title{
Türkiye’de İnşaat Mühendislerinin Mobbing Algılarının Belirlenmesi Üzerine Bir Çalışma
}

\author{
Hasan Basri BAŞAĞA ${ }^{1 *}$ D, Ünsa KARAL ${ }^{2}$, Bayram Ali TEMEL ${ }^{1}$ \\ ${ }^{1}$ Karadeniz Teknik Üniversitesi, Mühendislik Fakültesi, İnşaat Mühendisliği Bölümü, Trabzon, Türkiye \\ ${ }^{2}$ İller Bankas1, Erzurum Bölge Müdürlüğü, Erzurum, Türkiye
}

Geliş / Received: 15/11/2018, Kabul / Accepted: 08/04/2019

\begin{abstract}
Öz
Bu çalışmada, Türkiye' de (Trabzon ve Rize illeri ölçeğinde) çalışan inşaat mühendislerinin mobbing algılarının, demografik değişkenler karşısında değişim gösterip göstermediği saptanmaktadır. Bu amaçla, inşaat mühendislerinin mobbing algılarını ölçmek için Leymann'ın mobbing tipolojisinden faydalanılarak hazırlanan anket 214 inşaat mühendisine uygulanmıştır.

Araştırmanın evreni, 2015 yılında Rize ve Trabzon illerinde çalışan 1700 inşaat mühendisidir. Geliştirilen algı ölçeği, meslek ve cinsiyet farklılıkları göz önüne alınarak 230 çalışana uygulanmış olup, bunlardan 214'ü anketi doldurarak uygulamaya katılmışlardır. Anket üç ayrı bölümden oluşmaktadır. Birinci bölümde; kişisel bilgiler; ikinci bölümde, Mobbing (psikolojik şiddet) algı ölçeği; üçüncü bölümde de açıklayıcı bilgilere yer verilmiştir.

Araştırma verileri, SPSS 23.0 programında çözümlenmiş, frekans, yüzde, ortalama değerleri hesaplanarak incelenmiştir. Araştırmanın bulgularında; genel olarak, Rize ve Trabzon illerinde çalışan inşaat mühendislerinin ankette yer alan davranışlara maruz kalmadıkları gözlenmiştir. Çalışanların, Mobbing (psikolojik şiddet) algılarıyla ilgili tutumlarının cinsiyetlerine, yaşlarına, medeni durumlarına, eğitim durumlarına, çalıştıkları sektöre, haftalık çalışma sürelerine, aylık toplam kazançlarına ve son 10 yıl içerisinde kaç farklı işyerinde çalıştıklarına göre farklılaşmadığı, bulundukları işteki çalışma sürelerine ise göre dikkate değer bir farklılık gösterdiği saptanmıştır.
\end{abstract}

Anahtar Kelimeler: İnşaat Mühendisleri, İşyerinde Psikolojik Şiddet, Mobbing Algısı

\section{A Study on the Identification of Mobbing Perceptions of Civil Engineers in Turkey}

\begin{abstract}
In this study, mobbing perceptions of civil engineers working in Turkey (on the scale of Trabzon and Rize provinces) is determined whether they show changes in the face of demographic variables. For this purpose, a survey prepared by using Leymann's mobbing typology to measure mobbing perceptions of civil engineers was applied to 214 civil engineers.

The target population of this research is 1700 civil engineers who work in Trabzon and Rize in 2015. Regarding participants' differences in gender and occupation, the developed scale of perception is applied to 230 workers, 214 of whom also participated in a survey. There are three sections in the survey: In section one; personal details, in section two; the scale of perception of mobbing, in section three; explanatory information.

The data of survey is solved via SPSS 23.0 and analyzed by calculating the frequency, percentage and mean values. In the findings of this research, it was observed that civil engineers who work in Trabzon and Rize were not exposed to behaviours that stated in the survey. Also, workers' attitudes about feeling of mob are not differ from their gender, age, marital status, educational background, sector, weekly working hours, monthly total earnings, and number of different workplace that worked in ten years. However, it is determined that there is a significant relation between the attitudes about feeling of mob and working process in their present work.
\end{abstract}

Keywords: Civil Engineers, Psychological Violence at Work, Mobbing Perception 


\section{Giriş}

Çalışanların hayatlarını devam ettirebilmeleri için gereken parayı kazanmaları amacıyla düzenli olarak gerçekleştirdikleri faaliyetler bütününe iş denir. Bu faaliyetler, çalışanların hayatlarının büyük bir bölümünü kapsamakta ve ruhsal açıdan etkilenmelerine sebep olmaktadır. İş hayatında sağladığı istihdam gücü ve hitap ettiği iş kollarının fazlalığ 1 ile inşaat sektörü gelişmekte olan ülkelerin ekonomilerinde önemli bir yere sahiptir. Yıllar geçtikçe sektörde istenen özellikler artmakta ve gereklilikler fazlalaş̧ıkça istihdamda meydana gelen artışı da önemli ölçüde inşaat sektörü karşılamaktadır. İnşaat sektörünün ihtiyaç duyduğu teknik kısımdaki gelişmeler (mimarlık, mühendislik hizmetleri gibi), sektörün gelişimini olumlu etkilemekte ve farklı disiplinlerden yeni paydaşların dâhil olmasını sağlamaktadır.

İnşaat sektöründe üretimin çok farklı aşamalardan meydana gelmesi ve farklı uzmanlık alanlarının kullanılması, çalışanların istihdam organizasyonun esnek bir yapıda olmasını gerektirmektedir. Farklı uzmanlık alanları genellikle aynı anda kullanılmamakta, işin aşamasına göre devreye girmektedir. İnşaat sektöründe de diğer sektörler de olduğu gibi parada, zamanda ve kalitede ideal olanı gerçekleştirebilmek amacıyla çalışanlarının performanslarını en elverişli seviyeye çıkarmak ve bunu devam ettirebilmek için özen gösterilmektedir. Ancak, özellikle inşaat sektörünün çalışma koşullarının zorluğu, çalışanlarını tehlikeli bölgelerde, uzun saatler boyunca, zamana karşı yarışarak vb. çalışmaya zorlamaktadır. $\mathrm{Bu}$ durum da çalışan performansını olumsuz etkileyen tutum ve davranışların ortaya çıkmasına sebep olabilmektedir. Literatürde mobbing (psikolojik şiddet) olarak tanımlanan bu davranış çalışanların verimliliklerini olumsuz yönde etkileyen bir sorundur. Bir kişinin veya kişilerin başkalarına zarar vermek amacıyla sistematik şekilde yaptığ 1 kötü davranışların sonucunda oluşan mobbinge maruz kalan kişi maddi ve manevi zarar görmektedir.

\subsection{Literatür}

Mobbing, Heinz Leymann tarafindan "bir görüş ve inanç farklılı̆̆ dâhil olmak üzere çeşitli nedenlerden ötürü bir veya birkaç kişi tarafından sistematik bir şekilde yönlendirilen düşmanca ve etik olmayan bir iletişimi yansitan bir tür psikolojik terör ve cinsiyet ayrımcılığ 1 olarak tanımlanmaktadır" (Leymann, 1996). Latince "mobile vulgus" sözcügünden gelen "mobbing" kelimesi; rahatsızlık verme, taciz etme ve her türlü fiziksel ve ruhsal yorgunluğa neden olan olumsuz tutum ve davranışlar gibi anlamlar taşımaktadır. İngilizce'de ise "mob" eylemi, bir yerde toplanmak, saldırmak ve rahatsız etmek anlamında kullanılmaktadır (Genç and Erdiş; 2015).

Mobbing kavram1, ilk olarak 1960'lı yıllarda Avusturyalı bilim adamı Lorenz tarafindan hayvanların kendi aralarında ya da bir yabancıya karşı uyguladıkları taciz davranışı şeklinde tanımlanmıştır (Eser, 2008). Sonraki yıllarda ise İsveç'li bilim adamı Heinemann (1972), İsveç’te okul yaşantısında öğrenciler arasında görülen zorbalık ve taciz olaylarını ele almıştır. Ayrıca, çocuklar arasında görülen zorbalık ve şiddet hareketlerinin önünün alınamaması durumunda, mobbing nedeniyle mağdurların ümitsizlik ve korku gibi nedenlerle, intihara yönelebileceğini vurgulamıştır (Heinemann, 1972). 1980 ve 1990'l1 yllarda ise Leymann (1990; 1996), mobbing terimini iş hayatındaki baskı, şiddet ve yıldırma hareketlerini tanımlamak için kullanmıştır.

Mobbing üzerine yapılan çalışmalar genellikle ya farklı meslek grubundaki çalışanların mobbing algısını ölçmek ya da mobbing davranışının yapısını ortaya koymak amacıyla gerçekleştirilmektedir. Türkiye'de de bu başlıklarda benzer çalışmalar yapılmıştır. Milli eğitime bağlı kurumlarda 
Gülşen ve Kılıç (2014) okul öncesi öğretmenlerine, Ertürk ve Cemaloğlu (2014) ilköğretim okullarında çalışan öğretmen ve müdürlere, Çelik ve Peker (2010) İstanbul ilinde lise öğretmenlerine ve Kaya vd. (2012) Kastamonu ilinde ilköğretim okullarında görev yapan öğretmenlere yönelik mobbing araştırması yapmışlardır. Benzer çalışmalar üniversite hocaları ile öğrencileri için de gerçekleştirilmiştir. Şenerkal (2014), üniversitelerde akademik personele yönelik mobbing sürecinde mobbing davranışları ile akademisyenlerin sağlığ 1 ve bireysel performans ilişkisini araştırmış ve sonuç olarak mobbing davranışları ile mağdur olanların demografik özellikleri arasında anlamlı farkl1lık belirleyememiştir. Mete (2013), akademisyenlerin mobbinge maruz kalma durumlarını, nedenlerini, sonuçlarını araştırmak ve mobbingin akademisyenler üzerindeki etkilerini belirlemek amaciyla yaptığı çalışmada, mobbing olaylarının s1klıkla yaşanmasına yükseköğretim kurumlarının örgütsel yapısının sebep olduğu, mobbing uygulayanların tipolojisinin megoloman, mobbinge seyirci kalanların ise ikiyüzlü, mobbing mağdurlarının yönetimde astlardan veya başarılı kişilerden seçildiği sonucuna varmıştır. Serinkan et al. (2013) Pamukkale Üniversitesi öğrencilerinin, Cegenli ve Barlı (2013) Atatürk Üniversitesi'nde çalışan öğretim elemanlarının ve Aydan vd. (2012) özel eğitim kurumlarında görevlendirilen öğretim elemanlarının mobbing algılarını tespit etmeye yönelik çalışmalar yapmışlardır. Hastane çalışanlarına yönelik olarak Kocaman (2017) bir üniversite hastanesinde görev yapan hekimlerin ve Çakıroğlu ve Tengilimoğlu (2014) tıbbi sekreterlerin mobbing algılarını ve buna paralel oluşan etkileri incelemişlerdir. Ayrıca, özel sektörde farklı meslek gruplarında çalışanlar üzerine de mobbing ile ilgili çalışmalar gerçekleştirilmiştir. Genç ve Erdiş (2015) Adana ilinde inşaat mühendisleri özelinde teknik elemanların, Yüksel (2015) orta ve üst düzey yöneticilerin, Yıldırım ve Uysaloğlu (2012) bir lojistik şirketinde çalışanların ve Arslan (2007) Ankara'da bankacılık sektöründe çalışanların mobbing algılarını belirlemeye yönelik çalışmalar yapmışlardır.

Mobbing algısının farklı parametrelere göre incelenmesi ve bu şekilde mobbingi oluşturan unsurların daha net ortaya koyulması amacıyla da çalışmalar gerçekleştirilmiştir. Tutumlu (2017) iş yerlerinde mobbing algısı üzerine yaptığı araştırmada, çalışanların hangi yaşta olduklarının, cinsiyetlerinin ne olduğunun, eğitim durumlarının hangi düzeyde olduğunun, çalışma yılının az veya çok olmasının veya mobbingi bilip bilmemelerinin mobbingin etkilerini algilamada anlaml bir farklılı oluşturmadığını belirlemiştir. Türkeli (2015) mobbing ve mobbingin örgütsel bağl1lığa olan etkisini araştırmış, genç çalışanların deneyimliler tarafından mobbinge maruz bırakıldıklarını ortaya koymuştur. Baş ve Oral (2012) çalışanların mobbing davranışları ve karakter özellikleri ile ilişkisi üzerine yaptığı çalışmalarda, kişiliklerinin mobbinge maruz kalmalarını etkileyip etkilemediği incelenmiş, mağdurların kişilik özellikleri ile mobbinge karşı sergiledikleri tutumlar arasındaki bağ araştırılmıştır. Aldı̆ (2011) kurumda mobbing uygulamasının az şiddetten çoğa doğru gittiğini ve sirasıyla kişilerin kendilerini göstermelerine ve iletişimlerine, itibarlarına, hayat kalitelerine, mesleki statülerine, toplumsal ilişkilerine ve sağlıklarına yönelik uygulandığını ortaya koymuştur. Karavardar (2009) bazı kişilik özellikleri ile psikolojik şiddet arasındaki ilişski üzerine bir çalışma yapmış ve mobbing ile mobbinge karşı direnen kişilik özelliklerinden stresle baş etme yollarını kullanma, psikolojik olarak dayanıklılık, hakkını arama ve algılanan sosyal destek kavramlarını incelemiştir. 


\section{2. Çalışmanın amacı}

Bu çalışma, "Türkiye'de (Trabzon ve Rize illeri ölçeğinde) çalışan inşaat mühendislerinin mobbing algıları, demografik değişskenler karşısında değişim gösterir mi?" problemine cevap aramaktadır. $\mathrm{Bu}$ amaç doğrultusunda gerçekleştirilen bu çalışmada, Trabzon ve Rize illerinde kamu kurumları ile özel sektörde çalışan inşaat mühendislerinin (işverenler hariç) mobbing (psikolojik şiddet) algılarını belirlenmesi ve bu algı düzeylerinin çalışanların demografik değişkenleri karşısında değişim gösterip göstermediği saptanmaktadır. Elde edilen bulgular, benzer bir çalışma iklimine sahip gelişmekte olan diğer ülkeler için ön araştırma olarak kabul edilebileceği gibi hem uluslararası arenada hem de akademik ve pratik ortamdaki karşılaştırmalar için de farklı bir kıyaslama aracı olabilecektir.

\section{Materyal ve Metot}

$\mathrm{Bu}$ çalışmada araştırma deseni olarak nitel araştırma yöntemlerinden tarama çalışması, veri toplama aracı olarak da anket formu kullanılmıştır. İnşaat mühendislerinin mobbing algılarını ölçmek amacıyla hazırlanan anket 54 sorudan oluşan üç ayrı bölümden oluşmaktadır. Birinci bölümde; kişisel bilgiler; ikinci bölümde, mobbing alg1 ölçeği; üçüncü bölümde de mobbing nedenlerini ortaya koyabilecek sorulara yer verilmiştir. Çalışanların mobbing algılarını ölçmede Leymann'ın mobbing tipolojisindeki 45 mobbing (psikolojik şiddet) davranışından, uygulamanın yapılacağı kitle dikkate alınarak seçilen sorular kullanılmıştır (Leymann, 1996) Çalışmada kullanılan ankette yer alan soruları ölçmek için 5'li Likert tipi ölçek kullanılmış olup, ölçek puanlamasında;

- Hiç, Kesinlikle katılmıyorum, Hiç etkilenmedim, Hiçbir zaman= 1 puan

- Nadiren, Katılmiyorum, Etkilenmedim, Çok nadir $=2$ puan
- Bazen, Kararsızım, Kismen etkilendim, Bazen $=3$ puan

- Sik sık Katılıyorum, Etkilendim, Çoğu zaman= 4 puan

- Çok sık, Kesinlikle katılıyorum, Çok etkilendim, Her zaman $=5$ puan

olarak değerlendirilmektedir. Ölçek sonucunda, ortalama bir puan elde edilmektedir.

Sorular oluşturulmadan önce ilgili literatür taranarak anketin taslak formu hazırlanmıştır. $\mathrm{Bu}$ taslağın kapsam geçerliliği ve içeriği hakkında üç uzmanın görüşü alınmıştır. Uzmanlardan elde edilen eleştiriler ve öneriler doğrultusunda anketin ön uygulama formu oluşturulmuştur. Yapılacak anket çalışmasının sahada karşılaşılabilecek eksiklerinin ortaya çıkarılması, giderilmesi ve buna bağlı olarak daha sistematik, verimli ve güvenilir sonuçlar elde edilmesi açısından anket yapılmadan önce pilot bir uygulama yapılmıştır. $\mathrm{Bu}$ amaçla, anket formları özel sektörde çalışan 11 inşaat mühendisi ile yüz yüze doldurulmuştur. Pilot uygulamadan sonra, soru formlarında gözden kaçan imla hataları düzeltilmiş ve anlaşılması güç olan sorular anlaşılır hale getirilmiştir.

Araştırmanın evrenini, 2015 yılında Trabzon ve Rize illerinde çalışan 1700 inşaat mühendisi oluşturmaktadır. Araştırma; Trabzon ve Rize illerinin merkez ilçelerinde kamu ve özel sektörde çalışan inşaat mühendisleri üzerinde gerçekleştirilmiştir. $\mathrm{Bu}$ çalışma için asgari örneklem sayısı $\% 10$ hata oranı ve $\% 95$ güven oranına bağlı olarak tespit edilmiş ve 2015 Mart, Nisan ve Mayıs aylarında Trabzon (Ortahisar) ilinde 170 ve Rize (Merkez) ilinde 60 olmak üzere toplamda 230 adet anket uygulamasina gidilmiştir. Anketler, inşaat mühendislerinin bazıları ile yüz yüze bazıları ile de anketler dağıtılıp doldurulduktan sonra toplama şeklinde yapılmıştır. Anket çalışması rastgele seçilen 230 kişi ile gerçekleştirilmiş ancak 
214 kişi ile yapılan anket değerlendirmeye değer bulunmuştur.

Ankette yer alan sorular içerik bakımından değerlendirildiğinde, çalışanların mobbing'e uğramış olsalar dahi işlerini kaybetme korkusuyla bunu dile getirememesi ve/veya ankete cevap veren inşaat mühendislerinin yöneticilerinin cevapları görme olasılığına karşı gerçek cevabı vermeme eğiliminde olması söz konusu olabilmektedir. Dolayısıyla, bu durumlar araştırmanın kısıtlarını oluşturmaktadır.

Ankette kullanılan ölçeklerin, elde edilen veriler ile geçerliği ve iç tutarlılığı analiz edilmiştir. Bunun için de güvenilirlik analizi yapilarak Cronbach's Alfa $(\alpha)$ değeri hesaplanmıştır. Güvenilirlik analizi seçilen örneğin güvenilirliğini, tesadüfiliğini ve tutarlılığını test etmekte kullanılır. Sonucun güvenilir olup olmadığına Cronbach's Alpha $(\alpha)$ değerine göre karar verilir (Tavşancıl, 2002):

- $0.00 \leq \alpha<0.40$ güvenilir değildir,

- $0.40 \leq \alpha<0.60$ güvenilirliği düşük,

- $0.60 \leq \alpha<0.80$ oldukça güvenilir,

- $0.80 \leq \alpha<1.00$ yüksek derecede güvenilir.

Güvenirlik analizi sonucunda çalışmada kullanılan ölçeğin Cronbach Alpha $(\alpha)$ iç tutarlılık katsayısı 0.924 bulunmuştur. $\mathrm{Bu}$ değer ölçeğin güvenirliğinin yüksek olduğunu göstermektedir.

İstatistiksel analiz için gerekli veriler, soruları yazarlar tarafindan ve literatürde yer alan Leymann'ın mobbing algı ölçeği sorularından (Leymann, 1996) alınarak hazırlanan anketin inşaat mühendislerine uygulanması ile elde edilmiştir. Elde edilen verilerin çalışanların demografik bilgilerine ve mobbing alg1 düzeylerine bağlı olarak istatistiksel analizleri SPSS 23 (Statistical Package for the Social Sciences) programı kullanılarak yapılmıştır.
Elde edilen veriler betimsel analizler yapılarak yorumlanmıştır. Veriler hakkında ayrıntılı bilgi almak için betimsel istatistik analizleri yapılarak verilerin frekans dağılımları tespit edilmiştir. Frekans dağılımlarının betimlenmesinde frekans tabloları ve pasta grafikleri kullanılmıştır.

Ankete katılan inşaat mühendislerinin demografik özelliklerini gösteren cinsiyet, yaş, medeni durum ve eğitim düzeyi bilgileri Tablo 1'de verilmektedir.

Tablo 1. İnşaat mühendislerinin cinsiyet, yaş, medeni durum ve eğitim düzeyi dağılımı.

\begin{tabular}{|c|c|c|}
\hline Cinsiyet & Frekans, f & Yüzde, \% \\
\hline Erkek & 130 & 60.75 \\
\hline Kadın & 84 & 39.25 \\
\hline Toplam & 214 & 100 \\
\hline Yaş & Frekans, f & Yüzde, \% \\
\hline $20-30$ & 111 & 51.87 \\
\hline $31-40$ & 67 & 31.31 \\
\hline $41-50$ & 23 & 10.75 \\
\hline 51 ve üstü & 13 & 6.07 \\
\hline Toplam & 214 & 100 \\
\hline Medeni Durum & Frekans, f & Yüzde, \% \\
\hline Bekâr & 111 & 51.87 \\
\hline Evli & 103 & 48.13 \\
\hline Toplam & 214 & 100 \\
\hline Ĕ̆itim Düzeyi & Frekans, f & Yüzde, \% \\
\hline Lisans & 191 & 89.25 \\
\hline Lisansüstü & 23 & 10.75 \\
\hline Toplam & 214 & 100 \\
\hline
\end{tabular}

\section{Bulgular}

Türkiye'de (Trabzon ile Rize illerinde) kamu kurumlarında ve özel sektörde çalışan toplam 214 inşaat mühendisi ile yapılan anketler 
değerlendirmeye alınmıştır. Ankete katılan inşaat mühendislerinden elde edilen veriler hakkında ayrıntılı betimleyici bilgi almak için frekans analizi yapılmış ve verilerin frekans dağılımlarına bakılmıştır. Bu amaçla, çalışma örneklemi içinde yer alan çalışanların sorulara verdikleri cevaplar pasta grafikleri ve frekans dağılımları halinde elde edilmiştir.

Yapılan çalışmanın örneklemini oluşturan inşaat mühendislerinin çalıştıkları sektöre göre dağılımları Şekil 1'de verilmektedir. Çalışanların sektörlere göre dağılımı kamu ve özel olarak belirlenmiştir. Buna göre, örneklemin \%58.41'i özel sektörde, \%41.59'u ise kamu sektöründe çalışmaktadır.

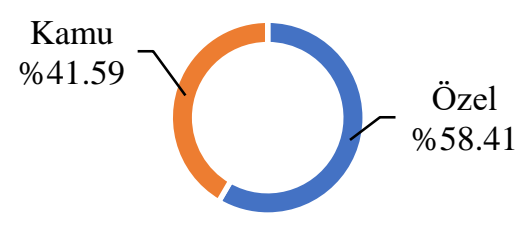

Şekil 1. Çalışanların inşaat sektöründeki çalışma alanlarına göre dağılımı.
Yapılan çalışmanın örneklemini oluşturan inşaat mühendislerinin haftalık çalışma süresine göre dağılımı Şekil 2'de verilmektedir. Buna göre, örneklemin \%5.4'ün 0-30 saat arası çalışanlar, $\% 66.82$ 'sini $31-50$ saat arası çalışanlar, \%28.04'ünü ise 51 saat ve üstü çalışanlar oluşturmaktadır.

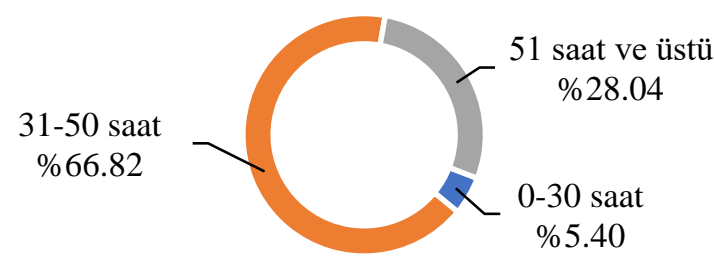

Şekil 2. Özel sektör çalışanlarının haftalık çalışma saatlerinin dağılımı.

Yapılan çalışmanın örneklemini oluşturan inşaat mühendislerinin mevcut işyerinde ne kadar süredir çalıştıklarının dağılımı Şekil 3 'te verilmektedir. Verilere göre, örneklemin $\% 52.80$ 'ini $0-24$ ay, \%20.56'sin1 25-60 ay, $\% 13.08$ 'ini $61-120$ ay, \%13.55'ini ise121 ay ve üstü çalışanlar oluşturmaktadır.

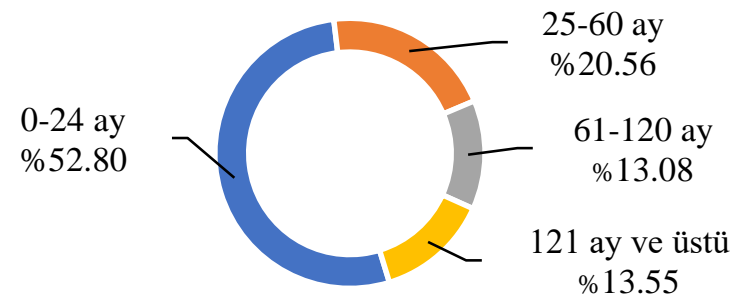

Şekil 3. Çalışanların mevcut iş yerinde ne kadar süredir çalıştıklarının dağılımı.

Yapılan çalışmanın örneklemini oluşturan inşaat mühendislerinin son 10 yılda kaç farklı işyerinde çalıştıklarının dağılım Şekil 4'te verilmektedir. Buna göre son 10 y1l içerisinde 2 ve 2 'den az iş yeri değiştirenler örneklemin \% 73.36 'sın1, 3 ve 3 'den fazla iş yeri değiştirenler örneklemin \%26.64'ünü oluşturmaktadır. 


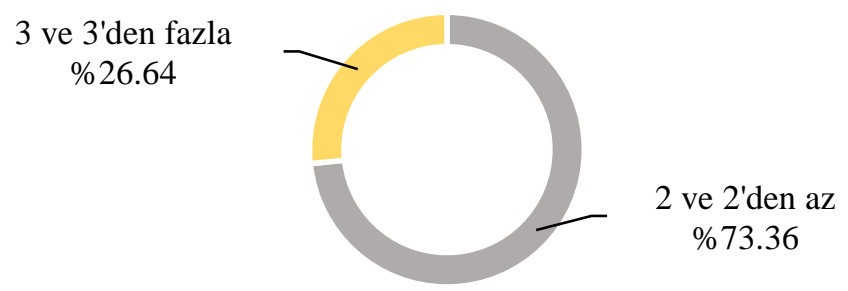

Şekil 4. Çalışanların son 10 yılda kaç farklı işyerinde çalıştıklarının dağılımı.

Yapılan çalışmanın örneklemini oluşturan inşaat mühendislerinin aylık gelir dağılımı Şekil 5'te verilmektedir. Buna göre, çalışanların \%29.44'ünün aylık geliri 1500 TL ve alt1, \%15.42'sinin 1501-2500 TL aras1, \%55.14'ünün 2501 TL ve daha fazla aylık geliri olduğu tespit edilmiştir. Buna göre, çalışma örneklemi içindeki inşaat mühendislerinin göz ardı edilemeyecek kadar kısmı asgari ücrete yakın maaşla çalışmaktadır. Bu durum da Türkiye'de inşaat mühendislerinin alacakları maaş ile ilgili yaptırımların ve kontrol mekanizmalarının olması gerektiğini göstermektedir.
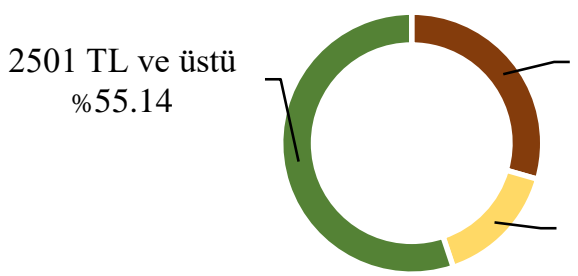

1500 TL ve alt 1 $\% 29.44$

1501-2500 TL aras1

$\% 15.42$

Şekil 5. Çalışanların aylık gelir dağılımı

Çalışma örneklemi içerisindeki inşaat mühendislerinin mobbing konusunda herhangi bir ön bilgiye sahip olup olmadıklarının dağılımı Şekil 6'da verilmektedir. Ankete cevap verenlerin çoğunluğu mobbing konusunda bir bilgi sahibi olduğunu ifade etmiştir. Ancak, bu konuda bilgi sahibi olmayan mühendislerin oranının da oldukça yüksek olduğu görülmektedir. 


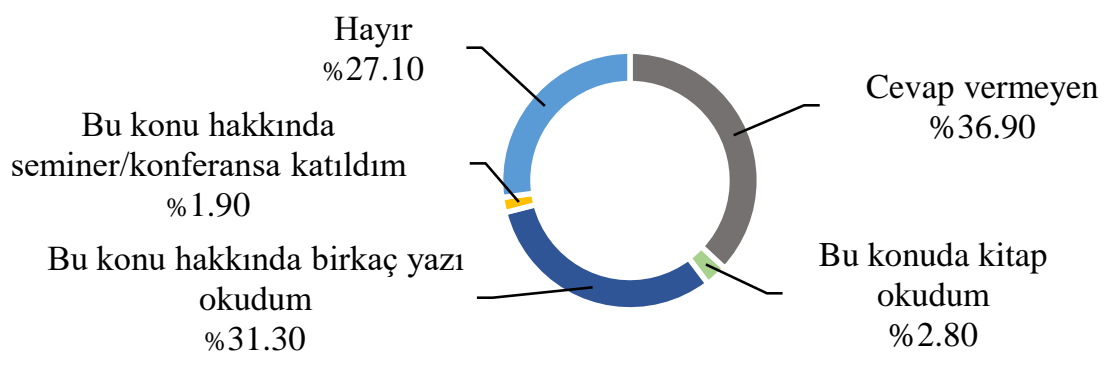

Şekil 6. Çalışanların mobbing konusunda herhangi bir ön bilgiye sahip olup olmadıklarının dağılımı.

Çalışma örneklemi içerisindeki inşaat mühendislerinin başkalarına mobbing uygulayıp uygulamadıklarının dağılımı Şekil 7'de verilmektedir. Bu sorunun cevabı kolaylıkla verilebilecek türden olmamasına rağmen, düşük bir yüzdeye sahip olsa da bazı mühendisler mobbing uyguladığını itiraf etmiştir.

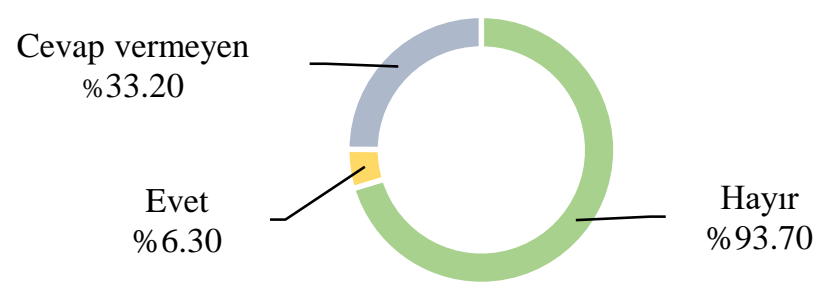

Şekil 7. Başkalarına mobbing uyguladınız mı sorusuna verilen cevapların dağılımı.

Çalışanların mobbing algısını ölçmek amaciyla Leymann'ın mobbing alg1 ölçeğindeki sorular kullanılarak ankete katılan inşaat mühendislerinden "hiç", "nadiren", "bazen", "sık sık" ve "çok sık" seçeneklerinden birini işaretlemesi istenmiştir. Elde edilen veriler 5'li Likert ölçeğine göre 1 =hiç'den $5=$ çok sık'a kadar puanlanarak her bir soruya verilen cevapların ortalaması hesaplanmıştır. Mobbing algısını ölçmek amacıyla sorulan sorulara verilen cevapların frekans, yüzde ve hesaplanan ortalama puan değerleri Tablo 2'de verilmektedir. 
Tablo 2. Mobbing algısını ölçmek amacıyla sorulan sorulara verilen cevapların frekans, yüzde ve ortalama puanları.

\begin{tabular}{|c|c|c|c|c|c|c|c|c|c|c|c|}
\hline $\begin{array}{l}\text { İfade } \\
\text { Puan }\end{array}$ & \multicolumn{2}{|c|}{$\begin{array}{l}\text { Hiç } \\
\text { (1) }\end{array}$} & \multicolumn{2}{|c|}{$\begin{array}{c}\text { Nadiren } \\
\text { (2) }\end{array}$} & \multicolumn{2}{|c|}{$\begin{array}{c}\text { Bazen } \\
(\mathbf{3})\end{array}$} & \multicolumn{2}{|c|}{$\begin{array}{l}\text { S1k s1k } \\
\text { (4) }\end{array}$} & \multicolumn{2}{|c|}{$\begin{array}{c}\text { Çok sik } \\
\text { (5) }\end{array}$} & \multirow[t]{2}{*}{ Ort, } \\
\hline & f & $\%$ & $\mathbf{f}$ & $\%$ & f & $\%$ & f & $\%$ & f & $\%$ & \\
\hline $\begin{array}{l}\text { 1. Üstünüz tarafından kendinizi ifade etmeniz } \\
\text { sınırlandı mı? }\end{array}$ & 105 & 49.1 & 50 & 23.4 & 47 & 22.0 & 5 & 2.3 & 7 & 3.3 & 1.87 \\
\hline 2. Sürekli olarak sözünüz kesildi mi? & 98 & 45.8 & 65 & 30.4 & 39 & 18.2 & 5 & 2.3 & 7 & 3.3 & 1.87 \\
\hline $\begin{array}{l}\text { 3. Meslektaşlarınız tarafından kendinizi ifade etmeniz } \\
\text { sinırlandı mı? }\end{array}$ & 138 & 64.5 & 46 & 21.5 & 24 & 11.2 & 2 & 0.9 & 4 & 1.9 & 1.54 \\
\hline $\begin{array}{l}\text { 4. Azarlandınız ve/veya size yüksek sesle bağırıldı } \\
\text { mı? }\end{array}$ & 133 & 62.1 & 45 & 21.0 & 29 & 13.6 & 6 & 2.8 & 1 & 0.5 & 1.58 \\
\hline $\begin{array}{l}\text { 5. İşinizle ilgili olarak yaptığınız her şey sürekli } \\
\text { eleştirildi mi? }\end{array}$ & 87 & 40.7 & 82 & 38.3 & 38 & 17.8 & 5 & 2.3 & 2 & 0.9 & 1.85 \\
\hline 6. Özel yaşamınız sürekli eleştirildi mi? & 175 & 81.8 & 23 & 10.7 & 11 & 5.1 & 5 & 2.3 & 0 & 0.0 & 1.28 \\
\hline 7. Yazılı ve/veya sözlü olarak tehdit edildiniz mi? & 170 & 79.4 & 22 & 10.3 & 18 & 8.4 & 4 & 1.9 & 0 & 0.0 & 1.33 \\
\hline 8. Telefonla rahatsiz edildiniz mi? & 177 & 82.7 & 20 & 9.3 & 13 & 6.1 & 3 & 1.4 & 1 & 0.5 & 1.28 \\
\hline 9. Yalancı olduğunuz ima edildi mi? & 186 & 86.9 & 15 & 7.0 & 12 & 5.6 & 1 & 0.5 & 0 & 0.0 & 1.20 \\
\hline 10. Etrafınızdakilerin sizinle konuşmadığı oldu mu? & 133 & 62.1 & 61 & 28.5 & 17 & 7.9 & 2 & 0.9 & 1 & 0.5 & 1.49 \\
\hline $\begin{array}{l}\text { 11. Sizinle konuşmanın meslektaşlarınıza yasaklandığ } 1 \\
\text { oldu mu? }\end{array}$ & 193 & 90.2 & 13 & 6.1 & 6 & 2.8 & 2 & 0.9 & 0 & 0.0 & 1.14 \\
\hline $\begin{array}{l}\text { 12. İş arkadaşlarınız tarafından size yokmuşsunuz gibi } \\
\text { davranıldı mı? }\end{array}$ & 181 & 84.6 & 17 & 7.9 & 11 & 5.1 & 3 & 1.4 & 2 & 0.9 & 1.26 \\
\hline 13. Arkanızdan kötü konuşuldu mu? & 134 & 62.6 & 51 & 23.8 & 19 & 8.9 & 5 & 2.3 & 5 & 2.3 & 1.58 \\
\hline 14. Hakkınızda asılsız söylentiler ortaya atıldı mı? & 156 & 72.9 & 32 & 15.0 & 18 & 8.4 & 4 & 1.9 & 4 & 1.9 & 1.45 \\
\hline 15. Gülünç durumlara düşürüldünüz mü? & 175 & & 24 & & 12 & & 3 & & 0 & 0.0 & \\
\hline 16. Size sanki akıl hastasıymış gibi davranıldı mı? & 198 & 92.5 & 4 & 1.9 & 8 & 3.7 & 3 & 1.4 & 1 & 0.5 & 1.15 \\
\hline $\begin{array}{l}\text { 17. Sizi gülünç duruma düşürmek için birtakım } \\
\text { davranışlarınız taklit edildi mi? }\end{array}$ & 181 & 84.6 & 23 & 10.7 & 8 & 3.7 & 2 & 0.9 & 0 & 0.0 & 1.21 \\
\hline 18. Politik inançlarınızla alay edildi mi? & 174 & 81.3 & 23 & 10.7 & 14 & 6.5 & 3 & 1.4 & 0 & 0.0 & 1.29 \\
\hline 19. Özel yaşamınızla alay edildi mi? & 192 & 89.7 & 14 & 6.5 & 8 & 3.7 & 0 & 0.0 & 0 & 0.0 & 1.14 \\
\hline 20. Dini inançlarınızla alay edildi mi? & 192 & 89.7 & 15 & & 4 & 1.9 & 1 & 0.5 & 2 & 0.9 & 1.16 \\
\hline $\begin{array}{l}\text { 21. Öz saygınızı etkileyecek bir iş yapmaya zorlandınız } \\
\text { mı? }\end{array}$ & 172 & 80.4 & 28 & 13.1 & 12 & 5.6 & 2 & 0.9 & 0 & 0.0 & 1.27 \\
\hline $\begin{array}{l}\text { 22. Çaba ve başarılarınızın haksız bir şekilde } \\
\text { değerlendirildiği oldu mu? }\end{array}$ & 111 & 51.9 & 51 & 23.8 & 45 & 21.0 & 3 & 1.4 & 1 & 0.5 & 1.80 \\
\hline 23. Küçük düşürücü isimlerle çağrıldığınız oldu mu? & 190 & 88.8 & 16 & 7.5 & 5 & 2.3 & 1 & 0.5 & 0 & 0.9 & 1.17 \\
\hline $\begin{array}{l}\text { 24. Şahsınıza sözle veya davranışla cinsel imalarda } \\
\text { bulunuldu mu? }\end{array}$ & 202 & 94.4 & 4 & 1.9 & 6 & 2.8 & 1 & 0.5 & 1 & 0.5 & 1.11 \\
\hline 25. Öz saygınızı etkileyen görevler verildi mi? & 170 & 79.4 & 28 & 13.1 & 11 & 5.1 & 3 & 1.4 & 1 & 0.5 & 1.35 \\
\hline 26. Anlamsız görevler verildi mi? & 95 & 44.4 & 55 & 25.7 & 55 & 25.7 & 5 & 2.3 & 4 & 1.9 & 1.92 \\
\hline $\begin{array}{l}\text { 27. Sahip olduğunuz yetenekten daha az yetenek } \\
\text { gerektiren işler aldınız mı? }\end{array}$ & 47 & 22.0 & 40 & 18.7 & 73 & 34.1 & 36 & 16.8 & 18 & 8.4 & 2.71 \\
\hline 28. Sürekli yeni görevler verildi mi? & 33 & 15.4 & 33 & 15.4 & 69 & 32.2 & 64 & 29.9 & 15 & 7.0 & 2.98 \\
\hline $\begin{array}{l}\text { 29. Gözden düşmeniz için niteliğinizin dışında görevler } \\
\text { verildi mi? }\end{array}$ & 160 & 74.8 & 29 & 13.6 & 18 & 8.4 & 6 & 2.8 & 1 & 0.5 & 1.41 \\
\hline $\begin{array}{l}\text { 30. Oluşan zararların faturasının size çıkarıldığı oldu } \\
\text { mu? }\end{array}$ & 151 & 70.6 & 27 & 12.6 & 27 & 12.6 & 8 & 3.7 & 1 & 0.5 & 1.51 \\
\hline $\begin{array}{l}\text { 31. Fiziksel olarak zor bir görev yapmaya zorlandınız } \\
\text { mı? }\end{array}$ & 154 & 72.0 & 25 & 11.7 & 30 & 14.0 & 5 & 2.3 & 0 & 0.0 & 1.47 \\
\hline 32. Fiziksel şiddete maruz kaldınız mı? & 205 & 95.8 & 3 & 1.4 & 6 & 2.8 & 0 & 0.0 & 0 & 0.0 & 1.07 \\
\hline 33. Hafif şiddetle tehdit edildiniz mi? & 185 & 86.4 & 20 & 9.3 & 9 & 4.2 & 0 & 0.0 & 0 & 0.0 & 1.18 \\
\hline 34. Fiziksel olarak taciz edildiniz mi? & 207 & 96.7 & 2 & 0.9 & 4 & 1.9 & 1 & 0.5 & 0 & 0.0 & 1.06 \\
\hline 35. Cinsel olarak taciz edildiniz mi? & 210 & 98.1 & 3 & 1.4 & 1 & 0.5 & 0 & 0.0 & 0 & 0.0 & 1.04 \\
\hline
\end{tabular}


Mobbing algısını ölçen soruların herhangi birine, verilen cevap skalasından "çok sık", "sik sik", "bazen" veya "nadiren" seçeneklerinden birini işaretleyenlere (193 kişi, \%90.2), maruz kaldıkları olumsuz tutum ve davranışların kendilerinde oluşturduğu duruma yönelik sorular sorulmuştur. $\mathrm{Bu}$ sorular ile verilen cevaplara ait bilgi ve veriler aşağıda verilmektedir.
Çalışanların, maruz kaldıkları olumsuz tutum ve davranışların kendi sağlıklarını ne derecede olumsuz etkilediğinin dağılımı Şekil 8'de verilmektedir. Buna göre, çalışanların yarıdan fazlası sağlıklarının olumsuz etkilenmediğini ifade etmiş, ancak geriye kalan kısım (sıklık periyotları değişmekle birlikte) sağlığının bozulduğunu belirtmiştir.

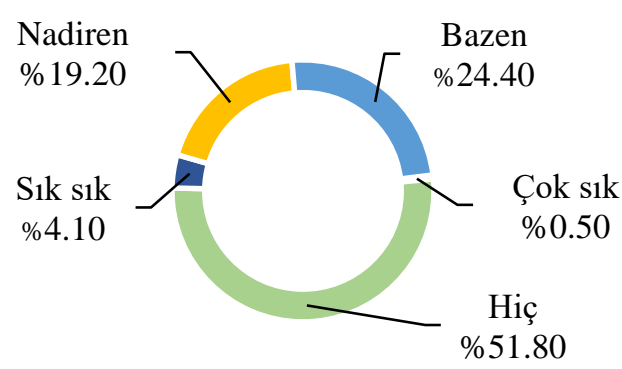

Şekil 8. Maruz kalınan olumsuz tutum ve davranışların kendi sağlıklarını ne derecede olumsuz etkilediğinin dağılımı.

Çalışanların, maruz kaldıkları olumsuz tutum ve davranışları başkaları ile paylaşıp paylaşmadıklarının dağılımı Şekil 9'da verilmektedir. Elde edilen sonuçlara göre ankete katılanların büyük çoğunluğu karşılaştığı problemi bir yakını ile paylaştığını ifade etmiştir. Bu durum gerek aile içinde gerekse arkadaş çevresinde sorunları ve sevinçleri paylaşan Türk toplumunun iş hayatındaki yansımasını göstermektedir.

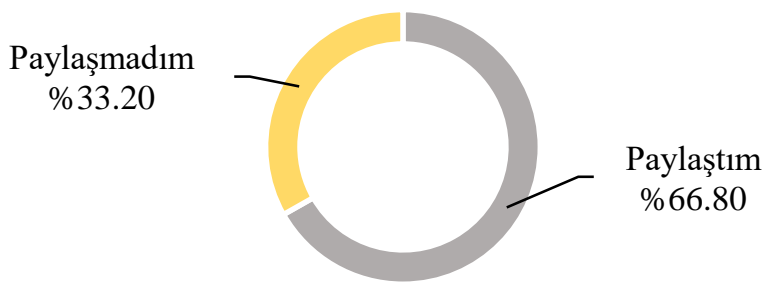

Şekil 9. Maruz kalınan olumsuz tutum ve davranışların başkaları ile paylaşıp paylaşmadıklarının dağılımı.

Çalışanların, maruz kaldıkları olumsuz tutum ve davranışların süresi bakımından dağılımı Şekil 10'da verilmektedir. Buna göre, çalışanların çoğunluğunun bu soruya 
cevap vermediği, ancak soruyu tutum ve davranışların takriben 3-6 ay cevaplayanların maruz kaldığı olumsuz arasında sürdüğü görülmektedir.

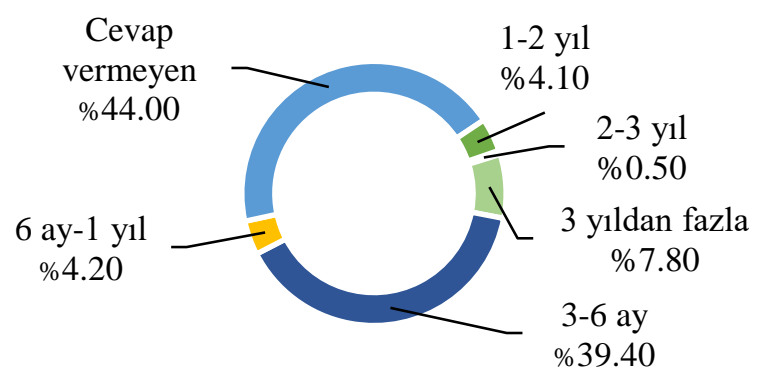

Şekil 10. Maruz kalınan olumsuz tutum ve davranışların süresi bakımından dağılımı.

Çalışanların maruz kaldıkları olumsuz tutum ve davranışların kimler tarafindan uygulandığının dağılımı Şekil 11'de verilmektedir. $\mathrm{Bu}$ soruya da ankete katılanların yarıya yakını cevap vermemiş, ancak soruyu cevaplayanların yarısından fazlası amir/patron düzeyinde çalışan insanlardan mobbing gördüğünü ifade etmiş. Düşük yüzdeye sahip olsa da çalışanların kendinden daha düşük pozisyonda çalışan kişilerin olumsuz tutum ve davranışlarına maruz kalması, bu davranışların sadece iş temelli olmadığını aynı zamanda olumsuz insan karakterinin iş ortamına yansıması olduğunu da göstermektedir.

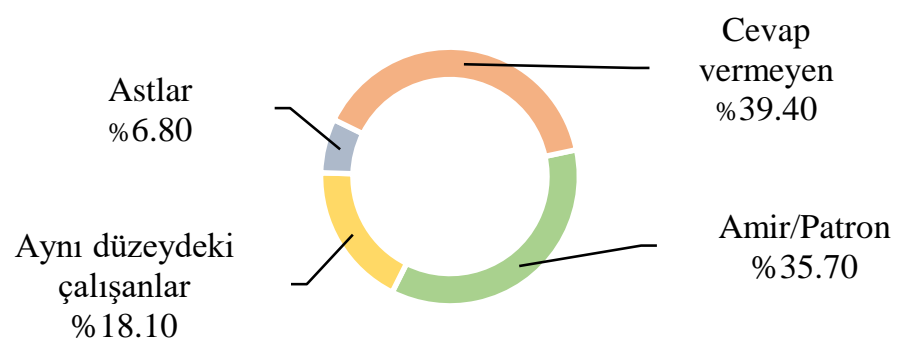

Şekil 11. Maruz kalınan olumsuz tutum ve davranışların kimler tarafından uygulandığının dağılımı.

Mobbing algısını ölçen soruların herhangi birine, verilen cevap skalasından "çok sık", "sik sik", "bazen" veya "nadiren" seçeneklerinden birini işaretleyen (193 kişi) çalışanlara, "İşyerinde maruz kaldığınız olumsuz tutum ve davranışları sergileyen kişiler bu hareketleri neden yapmış olabilir?" sorusu sorulmuştur ve kendilerine sunulan seçeneklere 5'li Likert ölçeğine göre "kesinlikle katılmiyorum" ile "kesinlikle katılıyorum" arasında belirtilen ifade ve puanlamadan birini işaretlemesi istenmiştir. Tablo 3'te bu soruya ait seçeneklerin 5'li Likert ölçeğine göre 1 (kesinlikle katılmiyorum)'den 5 (kesinlikle katılıyorum)'e kadar puanlanan verilerin frekans, yüzde ve ortalama değerleri verilmiştir. Elde edilen verilere göre baskın 
olarak ortaya çıkan bir sonuç olmamasına karşın en olası sebep olarak "İdarecilerin kişilik problemleri ya da şahsi kompleksleri" ve "Yerime kendi tanıdığını getirmek için" maddeleri belirlenmiştir. En düşük ihtimal olarak da "Güzel/yakışıklı olduğum için" ve "Yetenekli olduğum için" maddeleri tercih edilmiştir. Buna göre, olumsuz tutum ve davranışlara maruz kalan kişiler, bu davranışın nedeni olarak kişilerin kişilik problemlerini ve şahsi menfaatlerini ön plana çıkarmaktadır.

Tablo 3. "İşyerinde maruz kaldığınız olumsuz tutum ve davranışları sergileyen kişiler bu hareketleri neden yapmış olabilir?" sorusuna verilen cevapların frekans, yüzde ve puan ortalamaları.

\begin{tabular}{|c|c|c|c|c|c|c|c|c|c|c|c|c|}
\hline & İfade & \multirow{2}{*}{\multicolumn{2}{|c|}{$\begin{array}{c}\text { Kesinlikle } \\
\text { katılmiyorum } \\
\text { (1) }\end{array}$}} & \multirow{2}{*}{\multicolumn{2}{|c|}{$\begin{array}{c}\text { Katılmiyorum } \\
\text { (2) }\end{array}$}} & \multirow{2}{*}{\multicolumn{2}{|c|}{$\begin{array}{c}\text { Karasızım } \\
\text { (3) }\end{array}$}} & \multirow{2}{*}{\multicolumn{2}{|c|}{$\begin{array}{c}\text { Katıliyorum } \\
\text { (4) } \\
\end{array}$}} & \multirow{2}{*}{\multicolumn{2}{|c|}{$\begin{array}{c}\text { Kesinlikle } \\
\text { katıliyorum } \\
\text { (5) }\end{array}$}} & \multirow{3}{*}{ Ortalama } \\
\hline & Puan & & & & & & & & & & & \\
\hline & & f & $\%$ & f & $\%$ & $\mathbf{f}$ & $\%$ & f & $\%$ & $\mathbf{f}$ & $\%$ & \\
\hline \multicolumn{2}{|r|}{ 1. Güzel/yakışıklı olduğum için } & 117 & 60.6 & 36 & 18.7 & 17 & 8.8 & 12 & 6.2 & 11 & 5.7 & 1.77 \\
\hline \multicolumn{2}{|r|}{ 2. Dini inancim nedeniyle } & 129 & 66.8 & 37 & 19.2 & 12 & 6.2 & 6 & 3.1 & 9 & 4.7 & 1.59 \\
\hline \multicolumn{2}{|r|}{$\begin{array}{l}\text { 3. Yerime kendi tanıdığını } \\
\text { getirmek için }\end{array}$} & 117 & 60.6 & 36 & 18.7 & 19 & 9.8 & 10 & 5.2 & 11 & 5.7 & 1.76 \\
\hline \multicolumn{2}{|r|}{ 4. Egolarını tatmin etmek için } & 80 & 41.5 & 21 & 10.9 & 25 & 13.0 & 39 & 20.2 & 28 & 14.5 & 2.55 \\
\hline \multicolumn{2}{|r|}{$\begin{array}{l}\text { 5. İdarecilerin kişilik problemleri } \\
\text { ya da şahsi kompleksleri }\end{array}$} & 73 & 37.8 & 27 & 14.0 & 23 & 11.9 & 42 & 21.8 & 28 & 14.5 & 2.61 \\
\hline \multicolumn{2}{|r|}{ 6. Açık fikirli olduğum için } & 72 & 37.3 & 25 & 13.0 & 35 & 18.1 & 34 & 17.6 & 27 & 14.0 & 2.58 \\
\hline \multicolumn{2}{|r|}{ 7. Siyasi görüşüm nedeniyle } & 105 & 54.4 & 41 & 21.2 & 26 & 13.5 & 9 & 4.7 & 12 & 6.2 & 1.87 \\
\hline \multicolumn{2}{|r|}{ 8. Çıkarlarını engellediğim için } & 95 & 49.5 & 28 & 14.6 & 23 & 12.0 & 29 & 15.1 & 17 & 8.9 & 2.19 \\
\hline \multicolumn{2}{|r|}{ 9. Beni kıskandığ 1 için } & 100 & 51.8 & 26 & 13.5 & 29 & 15.0 & 23 & 11.9 & 15 & 7.8 & 2.1 \\
\hline \multicolumn{2}{|r|}{ 10. Yetenekli olduğum için } & 91 & 47.2 & 24 & 12.4 & 30 & 15.5 & 32 & 16.6 & 16 & 8.3 & 2.26 \\
\hline
\end{tabular}

Mobbing algısını ölçen soruların herhangi birine, verilen cevap skalasından "çok sık", "s1k s1k", "bazen" veya "nadiren" seçeneklerinden birini işaretleyen (193 kişi) çalışanlara, "İşyerinde olumsuz tutum ve davranışlara maruz kalınan dönemde bundan nasıl etkilendiniz?" sorusu sorulmuştur ve kendilerine sunulan seçeneklere 5'li Likert ölçeğine göre "hiç etkilenmedim" ile "çok etkilendim" arasında belirtilen ifade ve puanlamalardan birini işaretlemesi istenmiştir. Tablo 4'te bu soruya ait seçeneklerin 5'li Likert ölçeğine göre 1 (hiç etkilenmedim)'den 5 (çok etkilendim)'e kadar puanlanan verilerin frekans, yüzde ve ortalama değerleri verilmiştir. Elde edilen verilere göre ön plana çıkan bir sonuç olmamasına karşın hissedilen psikolojiyi en iyi tarif eden maddeler "Uyku düzenim bozuldu" ve "Stres yaşadım" olarak belirlenmiştir. En az gözlemlenen duygular ise "Kimseyle fiziksel temas kuramiyordum" ve "İşten kaçmak için sürekli bahaneler uyduruyordum" olarak tespit edilmiştir.

Mobbing algısını ölçen soruların herhangi birine, verilen cevap skalasından "çok sık", "s1k s1k", "bazen" veya "nadiren" seçeneklerinden birini işaretleyen (193 kişi) çalışanlara, "İşyerinde maruz kalınan olumsuz tutum ve davranışlara karş1 tutumunuz ne oldu?" sorusu sorulmuştur ve 
kendilerine sunulan seçeneklere 5'li Likert ölçeğine göre 1 (hiçbir zaman)'den 5 (her zaman)'e kadar arasında belirtilen ifadelerden birini işaretlemesi istenmiştir. Tablo 5'te bu soruya ait seçeneklerin 5'li Likert ölçeğine göre 1 (hiçbir zaman)'den 5 (her zaman)'e kadar puanlanan verilerin frekans, yüzde ve ortalama değerleri verilmiştir. Tablo 5'te yer alan sonuçlara göre, inşaat mühendislerinin işyerinde maruz kalınan olumsuz tutum ve davranışlara karşı görmezden geldiği ya da yapan kişiyle konuştuğu tespit edilmiştir.

Tablo 4. "İşyerinde olumsuz tutum ve davranışlara maruz kalınan dönemde bundan nasıl etkilendiniz?" sorusuna verilen cevapların frekans, yüzde ve puan ortalamaları.

\begin{tabular}{|c|c|c|c|c|c|c|c|c|c|c|c|c|}
\hline & $\begin{array}{l}\text { İfade } \\
\text { Puan }\end{array}$ & \multicolumn{2}{|c|}{$\begin{array}{c}\text { Hiç } \\
\text { etkilenmedim } \\
(\mathbf{1}) \\
\end{array}$} & \multicolumn{2}{|c|}{$\begin{array}{c}\text { Etkilendim } \\
\text { (2) } \\
\end{array}$} & \multicolumn{2}{|c|}{$\begin{array}{c}\text { Kismen } \\
\text { etkilendim } \\
(\mathbf{3}) \\
\end{array}$} & \multicolumn{2}{|c|}{$\begin{array}{c}\text { Etkilendim } \\
\text { (4) } \\
\end{array}$} & \multicolumn{2}{|c|}{$\begin{array}{l}\text { Çok etkilendim } \\
\text { (5) }\end{array}$} & \multirow[t]{2}{*}{ Ortalama } \\
\hline & & $\mathbf{f}$ & $\%$ & $\mathbf{f}$ & $\%$ & f & $\%$ & $\mathbf{f}$ & $\%$ & f & $\%$ & \\
\hline & Uyku düzenim bozuldu & 80 & 41.5 & 24 & 12.4 & 38 & 19.7 & 37 & 19.2 & 14 & 7.3 & 2.38 \\
\hline & $\begin{array}{l}\text { Hiç kimseye güvenim } \\
\text { kalmadı }\end{array}$ & 87 & 45.1 & 27 & 14.0 & 35 & 18.1 & 34 & 17.6 & 10 & 5.2 & 2.24 \\
\hline 3. & Bedensel hastalık yaşadım & 122 & 63.2 & 34 & 17.6 & 22 & 11.4 & 10 & 5.2 & 5 & 2.6 & 1.66 \\
\hline & Kendimi suçluyordum & 123 & 57.5 & 33 & 17.1 & 20 & 10.4 & 11 & 5.7 & 6 & 3.1 & 1.67 \\
\hline & $\begin{array}{l}\text { Kendimi sürekli yorgun } \\
\text { hissediyordum }\end{array}$ & 87 & 45.1 & 19 & 9.8 & 34 & 17.6 & 38 & 19.7 & 15 & 7.8 & 2.35 \\
\hline & $\begin{array}{l}\text { Kimseyle fiziksel temas } \\
\text { kuramıordum }\end{array}$ & 128 & 66.3 & 38 & 19.7 & 21 & 10.9 & 3 & 1.6 & 3 & 1.6 & 1.52 \\
\hline & $\begin{array}{l}\text { İşten kaçmak için sürekli } \\
\text { bahaneler uyduruyordum }\end{array}$ & 128 & 66.3 & 30 & 15.5 & 25 & 13.0 & 7 & 3.6 & 3 & 1.6 & 1.58 \\
\hline 8. & İşimden/işyerimden soğudum & 92 & 47.9 & 20 & 10.4 & 39 & 20.3 & 26 & 13.5 & 15 & 7.8 & 2.23 \\
\hline & Stres yaşadım & 68 & 35.2 & 16 & 8.3 & 47 & 24.4 & 46 & 23.8 & 16 & 8.3 & 2.61 \\
\hline & Psikolojik hastalık yaşadım & 125 & 64.8 & 36 & 18.7 & 18 & 9.3 & 8 & 4.1 & 6 & 3.1 & 1.62 \\
\hline & . Kendime güvenim kalmadı & 129 & 66.8 & 35 & 18.1 & 14 & 7.3 & 7 & 3.6 & 8 & 4.1 & 1.60 \\
\hline
\end{tabular}

Tablo 5. "İşyerinde maruz kalınan olumsuz tutum ve davranışlara karşı tutumunuz ne oldu?" sorusuna verilen cevapların frekans, yüzde ve puan ortalamaları.

\begin{tabular}{|c|c|c|c|c|c|c|c|c|c|c|c|c|}
\hline & $\begin{array}{l}\text { İfade } \\
\text { Puan }\end{array}$ & \multicolumn{2}{|c|}{$\begin{array}{c}\text { Hiçbir zaman } \\
\text { (1) }\end{array}$} & \multicolumn{2}{|c|}{$\begin{array}{c}\text { Çok nadir } \\
(\mathbf{2}) \\
\end{array}$} & \multicolumn{2}{|c|}{$\begin{array}{c}\text { Bazen } \\
(\mathbf{3})\end{array}$} & \multicolumn{2}{|c|}{$\begin{array}{c}\text { Çoğu zaman } \\
\text { (4) }\end{array}$} & \multicolumn{2}{|c|}{$\begin{array}{c}\text { Her zaman } \\
(\mathbf{5})\end{array}$} & \multirow[t]{2}{*}{ Ortalama } \\
\hline & & $\mathbf{f}$ & $\%$ & f & $\%$ & f & $\%$ & f & $\%$ & f & $\%$ & \\
\hline & Üstlere şikâyet etme & 123 & 63.7 & 35 & 18.1 & 28 & 14.5 & 7 & 3.6 & 0 & 0.0 & 1.58 \\
\hline & Yapan kişiyle konuşma & 76 & 39.4 & 27 & 14.0 & 37 & 19.2 & 36 & 18.7 & 17 & 8.8 & 2.44 \\
\hline 3. & Hukuki yollara başvurma & 166 & 86.0 & 13 & 5.7 & 5 & 2.6 & 8 & 4.1 & 1 & 0.5 & 1.26 \\
\hline & Görmezden gelme & 81 & 42.0 & 16 & 8.3 & 41 & 21.2 & 44 & 22.8 & 11 & 5.7 & 2.42 \\
\hline 5. & $\begin{array}{l}\text { Başka pozisyona ya da görev } \\
\text { yerine tayin talebi }\end{array}$ & 154 & 80.2 & 17 & 8.9 & 17 & 8.9 & 4 & 2.1 & 0 & 0.0 & 1.33 \\
\hline 6. & Hiçbir şey & 106 & 54.9 & 12 & 6.2 & 39 & 20.2 & 27 & 14.0 & 9 & 4.7 & 2.07 \\
\hline
\end{tabular}

Mobbing algısını ölçen soruların herhangi birine, verilen cevap skalasından "çok sık", "s1k s1k", "bazen" veya "nadiren" seçeneklerinden birini işaretleyen (193 kişi) çalışanlara, "İşyerinde olumsuz tutum ve davranışlara maruz kalınan dönemde çevrenizdeki insanların size karşı davranışı nasıl olmuştur?" sorusu sorulmuştur ve 
kendilerine sunulan seçeneklere 5'li Likert ölçeğine göre 1 (hiçbir zaman)'den 5 (her zaman)'e kadar arasında belirtilen ifadelerden birini işaretlemesi istenmiştir. Tablo 6'da bu soruya ait seçeneklerin 5'li
Likert ölçeğine göre 1 (hiçbir zaman)'den 5 (her zaman)'e kadar puanlanan verilerin frekans, yüzde ve ortalama değerleri verilmiştir.

Tablo 6. "Iş̧yerinde olumsuz tutum ve davranışlara maruz kalınan dönemde çevrenizdeki insanların size karşı davranışı nasıl olmuştur?” sorusuna verilen cevapların frekans, yüzde ve puan ortalamalar1.

\begin{tabular}{|c|c|c|c|c|c|c|c|c|c|c|c|c|}
\hline & $\begin{array}{l}\text { İfade } \\
\text { Puan }\end{array}$ & \multicolumn{2}{|c|}{$\begin{array}{c}\text { Hiçbir zaman } \\
\text { (1) }\end{array}$} & \multicolumn{2}{|c|}{$\begin{array}{l}\text { Çok nadir } \\
\text { (2) }\end{array}$} & \multicolumn{2}{|c|}{$\begin{array}{c}\text { Bazen } \\
(\mathbf{3})\end{array}$} & \multicolumn{2}{|c|}{$\begin{array}{c}\text { Çoğu zaman } \\
\text { (4) }\end{array}$} & \multicolumn{2}{|c|}{$\begin{array}{l}\text { Her zaman } \\
\qquad(\mathbf{5})\end{array}$} & \multirow{2}{*}{ Ortalama } \\
\hline & & $\mathbf{f}$ & $\%$ & $\mathbf{f}$ & $\%$ & $\mathbf{f}$ & $\%$ & $\mathbf{f}$ & $\%$ & f & $\%$ & \\
\hline & Ailemden destek gördüm & 60 & 31.1 & 7 & 3.6 & 20 & 10.4 & 30 & 15.5 & 76 & 39.4 & 3.29 \\
\hline 2. & $\begin{array}{l}\text { Herkes beni haksız buldu/tavır } \\
\text { aldı }\end{array}$ & 147 & 68.7 & 26 & 13.5 & 15 & 7.8 & 2 & 1.0 & 3 & 1.6 & 1.38 \\
\hline 3. & $\begin{array}{l}\text { İşyerindeki arkadaşlarımdan } \\
\text { destek gördüm }\end{array}$ & 55 & 28.5 & 13 & 6.7 & 39 & 20.2 & 44 & 22.8 & 42 & 21.8 & 3.02 \\
\hline & $\begin{array}{l}\text { Arkadaşlarım } \\
\text { cezalandırılacakları korkusu } \\
\text { ile benden uzaklaştı }\end{array}$ & 145 & 75.1 & 18 & 9.3 & 25 & 13.0 & 2 & 1.0 & 3 & 1.6 & 1.44 \\
\hline 5 . & $\begin{array}{l}\text { İşyerindeki yakın } \\
\text { arkadaşlarım cezalandırıldı }\end{array}$ & 158 & 81.9 & 12 & 6.2 & 21 & 10.9 & 2 & 1.0 & 0 & 0.0 & 1.32 \\
\hline 6 . & $\begin{array}{l}\text { Hiç kimseden destek } \\
\text { görmedim }\end{array}$ & 135 & 69.9 & 16 & 8.3 & 24 & 12.4 & 4 & 2.1 & 14 & 7.3 & 1.68 \\
\hline
\end{tabular}

\section{4. İrdeleme ve Tartışma}

İnşaat mühendislerinin mobbing algısını ölçmek için Leymann tipolojisinden sorulan 35 sorudan 33 tanesinin ortalaması 1 (hiç) ile 2 (nadiren) arasında elde edilmiş olup, 2'yi geçen ve en yüksek değer alan sorular "Sahip olduğunuz yetenekten daha az yetenek gerektiren işler aldınız mı?" ve "Sürekli yeni görevler verildi mi?" olmuştur. 1'e yakın dolayısıyla en düşük değer alan sorular ise "Fiziksel şiddete maruz kaldınız mı?", "Fiziksel olarak taciz edildiniz mi?" ve "Cinsel olarak taciz edildiniz mi?" sorularıdır.

İnşaat mühendislerinin demografik özellikleri dikkate alınmadan araştırmaya katılan 214 inşaat mühendisinin toplam alg1 puanları ortalaması 50.98 olarak elde edilmiştir. Bu sonuç Tablo 7'de verilen alg1 ölçeği skalasına göre "Hiç" anlamı taşımaktadır. Buna göre, genel olarak inşaat mühendislerinin mobbingi temsil eden tutum ve davranışlara maruz kalmadığ 1 tespit edilmiştir. 
Tablo 7. Algı ölçeği seçenekleri ile ortalama arasındaki ilişki.

\begin{tabular}{lcc}
\hline $\begin{array}{l}\text { Puan } \\
\text { (Ölçek Bazında) }\end{array}$ & $\begin{array}{c}\text { Ölçek x214 } \\
\text { (Toplam Bazında) }\end{array}$ & $\begin{array}{c}\text { Alan } \\
(+,-\% 50)\end{array}$ \\
\hline 1 (Hiç) & 43 & $43-63$ \\
2 (Nadiren) & 86 & $64-106$ \\
3 (Bazen) & 128 & $107-149$ \\
4 (Sik s1k) & 171 & $150-192$ \\
5 (Çok s1k) & 214 & $193-214$ \\
\hline
\end{tabular}

Mobbing alg1 tipolojisinde en yüksek ortalamaya sahip sorular irdelendiğinde inşaat sektörünün çalışma hayatının özelliklerinden kaynaklandığ1 görülmektedir. İnşaat sektöründe yapılan projelerin her zaman bir süresi vardır ve projenin bitiş zamanı proje başlarken bellidir. Ancak, genellikle projenin yapım süreci bu kısıtlı zaman dikkate alınarak bir planlama çerçevesinde yürütülmez. Doğal olarak bu durum beraberinde dağınık iş görmeyi getirdiğinden işin yapım süreci boyunca devamlı bir acele iş görme eğilimi ortaya çıkmaktadır. Böyle bir ortamda çalışanların görev dağılımları ve sorumlulukları da net olarak ortaya koyulmadığından süreç içerisinde işler rastgele dağıtılabilmektedir. $\mathrm{Bu}$ durum da yapılan çalışmada sürekli yeni görevler verilmesi ve sahip olunan yetenekten daha az yetenek gerektiren işlerin verilmesi maddelerinin ön plana çıkmasını sağlamıştır. Ayrıca, bu maddelerin diğer maddelere göre daha yüksek ortalamaya sahip olmasını sağlayan diğer bir sebebin de inşaat mühendisi sayısının çok olması, ancak, işverenlerin işin gerektirdiği kadar mühendisi istihdam etmemesinden kaynaklandığı düşünülmektedir. İşverenler az mühendis ile çok fazla iş görmek istediklerinden bir insanın kaldırabileceği yükten daha fazla görev ve sorumluluk ile ona bask1 uygulayabilmektedir. Ayrıca, elindeki elemanı her işte kullanma mantığı ile teknikerin veya normal bir çalışanın yapacağı işler de inşaat mühendislerine verilebilmektedir.
Kamuda çalışan inşaat mühendisleri için ise durum özel sektörde çalışanlara göre farklılık göstermektedir. Bazı kurumlarda inşaat mühendisi fazlalığı yaşanırken bazı kurumlarda ise tam tersi bir durum söz konusudur. İster fazlallk olsun ister az inşaat mühendisi olsun çalışan, işi beceren kişiler her zaman daha fazla iş ile meşgul edilmektedir. Dolayısıyla, sürekli yeni görev verilmesi de kaçınılmaz olabilmektedir. Fazla mühendis olmas1 durumunda ise kişiyi iş ile meşgul etme amaciyla kişinin yeteneği sorgulanmadan görev tahsis edilebilmektedir.

Mobbing algısını ölçen sorulardan en düşük ortalamaya sahip cevaplar taciz ile ilgili sorulardan elde edilmiştir. Ancak, Türk toplum yapısından dolayı insanlar olumsuz olayları saklama veya üçüncü şahıslarla paylaşmama davranışını geliştirmiştir. Dolayisıyla, bu durum taciz ile ilgili sorulara verilen cevapların tam anlamıyla gerçeği yansıtıp yansıtmadığı konusunda şüphe uyandırmaktadır. Ayrıca, bu sorulara verilen cevapların ortalamaları düşük olsa bile bu sonuç, bu ortalamayı ortaya çıkaracak nadir de olsa eyleme maruz kalan inşaat mühendisleri olduğunu göstermektedir.

Mobbing algısını ölçen sorulardan "hiç" dışındaki seçeneklerden herhangi birini işaretleyen inşaat mühendislerine maruz kaldıkları olumsuz tutum ve davranışları daha detaylı ortaya koyabilmek amaciyla sorular sorulmuştur. Ortalama mobbing algısı hiç kategorisinde çıktığından buna 
paralel olarak sorulan sorularda da düşük puanlar elde edilmiştir.

Olumsuz tutum ve davranışları gerçekleştirenlerin sebeplerini ortaya koymak amaciyla sorulan sorulara verilen cevapların ortalamalarının hepsi 3'ün altında çıkmıştır. Bu sebeplerden en yüksek ortalamaya sahip sebepler "İdarecilerin kişilik problemleri ya da şahsi kompleksleri" ile "Açık fikirli olduğum için" olarak belirlenirken, en düşük ihtimalli sebep olarak da "Dini inancım nedeniyle" sebebi tespit edilmiştir.

Olumsuz tutum ve davranışlardan etkilenme şekli ile ilgili sorulan soruya verilen cevaplardan herhangi birine bir yoğunlaşma oluşmamış ve ortalamaların hepsi 3'ün altında kalmıştır. Verilen cevaplara göre olumsuz tutum ve davranışlara maruz kalınan dönemde mağdurlar en çok stres yaşamış ve uyku düzeni bozulmuştur. En az belirti gösteren problem ise "Kimseyle fiziksel temas kuramıyordum" seçeneği olmuştur.

Olumsuz tutum ve davranışlara karşı nasıl bir tutum sergilendiği ile ilgili sonuçlarda herhangi bir tutuma yoğunlaşma oluşmamış ve ortalamaların hepsi 3'ün altında kalmıştır. Verilen cevaplara göre olumsuz tutum ve davranışlara karşı geliştirilen tutumların başında "Yapan kişiyle konuşma" gelmektedir. Çalışmada, en az sergilenecek davranış olarak "Hukuki yollara başvurma" seçeneği çıkmıştır. Bu durum, çalışanların kendi haklarını koruma hususunda mahkemeleri en son seçenek olarak düşündügünü göstermektedir.

Türk toplumunun aile merkezli yapısı, inşaat mühendislerinin olumsuz tutum ve davranışlara maruz kaldığı dönemde çevresindeki insanların davranışının sorulduğu soruya verilen cevapta ortaya çıkmaktadır. Elde edilen sonuçlarda en fazla ortalamaya sahip cevap "Ailemden destek gördüm" olmuştur. En az ortalamaya sahip cevap ise "İşyerindeki yakın arkadaşlarım cezalandırıldı" seçeneği olarak belirlenmiştir. Buna göre, yapılan tutum ve davranışlar kişisel olup bu davranışlara maruz kalanların yakın çevresine genel olarak sıçramamaktadır.

Literatürde mobbing algısı farklı sektörlerde yapılan çalışmalarla ortaya koyulmuştur. Dilman (2007) özel hastanelerde çalışan hemşirelerin, Gökçe (2006) öğretmenlerin, . Solakoğlu (2007) sağlık çalışanlarının, Yavuz (2007) Tıp fakültesi çalışanlarının, Aldığ (2011) ise bir iş yeri çalışanlarının mobbinge maruz kalma durumları ile ilgili yaptıkları araştırmalarında en sı karşılaşılan davranışın "Çalışmakta olduğum kurumda sürekli olarak konuşurken sözüm kesiliyor" ifadesi olduğu tespit edilmiştir. Sözün kesilmesi bu çalışmalarda en çok karşılaşılan durum olurken bu çalışma kapsamında elde edilen sonuçlarda nadiren kategorisine girmektedir. İnşaat mühendisleri daha çok sorumluluk alan tarafta olduğundan ve genel olarak yapılacak işler ve sırası belli olduğundan üstleri ile iletişimleri sınırlı ve genellikle bilgilendirme şeklinde olmaktadır. Dolayısıyla, söz kesme unsuru diğer meslek gruplarının aksine bu çalışmada baskın çıkmamıştır.

Mobbinge maruz kalan inşaat mühendislerinin bu tutum karşısında en çok gösterdikleri davranış şekli Yavuz'un (2007) çalışmasında çoğunlukla "Yazılı olarak şikayet ederdim" şeklindedir. Ekiz'in (2010) işletmelerde yaşanan psikolojik şiddet çalışmasında çoğunlukla "Yapan kişiyle konuşma" olarak belirlenmiştir. Yapılan çalışmalar incelendiğinde çoğunluğu bu iki şikayet şeklinin oluşturduğu görülmektedir. Hukuki yollara başvuru bu çalışmada olduğu gibi diğer çalışmalarda da çok sık rastlanan bir yol olarak ortaya 
çıkmamaktadır. Kişiler kendi problemlerini genellikle kendileri çözme yoluna gitmektedir.

Olumsuz tutum ve davranışlardan etkilenme şekilleri ve bu davranışın birileri ile paylaşılması diğer sektörlerde de yapılan araştırmalarda (Arslan 2007, Bingöl 2007, Dangaç 2007, Doğan 2009 ve Ertek 2009) çoğunlukla bu çalışmada elde edilen sonuçlarla paralellik göstermektedir. Bu sonuçlar; "Mağdur sorunu yakın çevresiyle paylaşır", "Strese ve depresyona girmeme neden oldu", "İş yerimde kendimi yalnız hissediyorum, kimseye güvenemiyorum", "Sinirli olmama neden oldu" ve "Uykuya dalmakta veya uyumakta güçlük çekmeme neden oldu" şeklinde karşımıza çıkmaktadır.

\section{Sonuç ve Öneriler}

Bu çalışmada, Türkiye'de (Rize ve Trabzon illeri ölçeğinde) çalışan inşaat mühendislerinin mobbing algıları ile çeşitli değişkenlere bağlı değişimi incelenmiştir. Leymann'in mobbing tipolojisinden alınan 35 soruluk skala ile yapılan çalışmada, ayrıca, verilen cevaplara bağlı olarak olumsuz tutum ve davranışın çerçevesini daha iyi belirleyebilmek amacıyla çalışma genişletilmiştir. Demografik özelliklerine bağlı olarak mobbing algısının değişip değişmediğini belirlemek amacıyla yöneltilen demografik sorulardan örneklem içinde bulunan ve özel sektörde çalışan inşaat mühendislerinin yarısının asgari ücret seviyesinde çalıştığı belirlenmiştir. Bu durum, Türkiye'de eğitimli ve teknik bir elemanın bile asgari ücret seviyelerinde çalışabileceğinin bir göstergesi olup bu konuda yetkili makamların önlem alması gerekmektedir.

Çalışmaya katılan inşaat mühendislerinin büyük çoğunluğu skala kapsamındaki sorulardan herhangi birine maruz kaldığını ifade etmiştir. 35 soru tek tek analiz edildiğinde, sorulara verilen cevapların ortalamalarına göre mobbingi belirleyen unsurların inşaat mühendisleri tarafından algılanma düzeyleri genel olarak 1 (Hiç) ile 2 (Nadiren) arasında çıkmıştır. Çalışmaya katılan inşaat mühendislerinin ortalama alg1 puanlamasına göre de mobbing algısı "hiç" kategorisine girmiştir. Sorulan sorularda sadece iki soruya verilen cevapların ortalamasında 3 (Bazen)'e yaklaşılmıştır: 1. Sürekli yeni görevler verildi mi? 2. Sahip olduğunuz yetenekten daha az yetenek gerektiren işler aldınız mi? Mobbingi belirleyen sorular içerisinde en düşük ortalama cinsel ve fiziksel şiddete maruz kalıp kalmadıklarının sorulduğu sorularda çıkmıştır. Ancak, bu soruların ortalamalarının "hiç" çıkmaması, çok az da olsa bu tür uygulamalara maruz kalan inşaat mühendislerinin olduğunu göstermektedir.

Mobbingi belirleyen sorulardan herhangi birisine olumlu cevap veren inşaat mühendislerinin çoğunluğu;

$$
\begin{aligned}
& \checkmark \text { Mobbingden dolayı sağlıklarının } \\
& \text { etkilenmediğini, etkilenenlerin ise } \\
& \text { en çok stres yaşadığını ve uyku } \\
& \text { düzeninin bozulduğunu, } \\
& \checkmark \text { Mobbing olayını birisiyle } \\
& \text { paylaştığını ve bu kişilerin } \\
& \text { çoğunlukla ailesi olduğunu, } \\
& \checkmark \text { Mobbingi uygulayanların } \\
& \text { amir/patron olduğunu ve kişilik } \\
& \text { problemleri ya da şahsi } \\
& \text { kompleksleri olduğundan bu } \\
& \text { davranışı sergilediklerini, } \\
& \checkmark \text { Mobbing olayını sonlandırmak için } \\
& \text { yapan kişi ile konuştuğunu, }
\end{aligned}
$$

ifade etmiştir.

Diğer sektörlerde mobbing algısını belirleyen çalışmaların sonuçları ile bu çalışmanın sonuçları karşılaştırıldığında genellikle öne çıkan mobbing unsurlarında 
farklılık olduğu ancak mobbing ile ilgili sorulan detay soruların cevaplarında benzerlikler olduğu görülmüştür.

Yapılan bu çalışmada dikkate alınamayan ancak gelecek çalışmalara yol gösterebilecek öneriler aşağıda verilmiştir:

* Mobbing algisının daha iyi belirlenebilmesi için bu çalışmanın sadece aktif çalışanlara değil aynı zamanda herhangi bir sebeple işten yeni ayrılmış olanlarla da yapılması önerilmektedir.

* Bu çalışma sadece Trabzon ve Rize illerinde çalışan inşaat mühendisleri ile yapılmıştır. Çalışmanın bölgeleri temsil edebilecek farklı illerdeki mühendislerle yapılması sayesinde mobbingin bölgesel olarak fark edip etmeyeceği de araştırılabilir.

* Özel sektörde çalışan inşaat mühendisleri çalıştıkları yerlere göre sinıflandirılarak mobbing algısının değişimi daha detaylı irdelenebilir. Benzer şekilde kamu sektörü de kurumlara göre detaylı olarak irdelenebilir.

\section{Kaynaklar}

Aldı̆̆, E., 2011. "İş yerinde yıldırma (mobbing) ve örnek bir çalışma", Yüksek Lisans Tezi, Doğuş Üniversitesi Sosyal Bilimler Enstitüsü, İstanbul.

Arslan, F., 2007. "İşletmelerde duygusal zorbalık ve ankara'da bankacılık sektöründe duygusal zorbalığın varlığına ilişkin bir uygulama", Yüksek Lisans Tezi, Niğde Üniversitesi Sosyal Bilimler Enstitüsü, Niğde.

Aydan, A., Mustafa, O., Tuna, S., 2012. Behaviors perceived as mobbing by the instructors assigned in special education institutions. Procedia-Social and Behavioral Sciences, 46, 4858-4863.
Baş, N., Oral, T., 2012. Mobbing Davranış1 ve Kişilik Özellikleriyle İlişkisi, İstanbul Ticaret Üniversitesi Sosyal Bilimler Dergisi,11,21, 11-24.

Bingöl, B., 2007. "İşyerinde yıldırma (mobbing) ve yıldırma üzerine bir araştırma", Yüksek Lisans Tezi, Dokuz Eylül Üniversitesi Sosyal Bilimler Enstitüsü, İzmir.

Cegenli, M.Z., Barlı, Ö., 2013. The exposure of psychological violence (mobbing) in universities and an application to the academicians. Procedia-Social and Behavioral Sciences, 93, 1174-1178.

Çakıroğlu, E., Tengilimoğlu, D., 2014. Mobbing (Yıldırma) Davranışlarının Tıbbi Sekreterlerin Tükenmişliği Üzerine Etkisi, Electronic Journal of Vocational Colleges Ağustos Özel Sayısı,167-188.

Çelik, S., Peker, S., 2010. Mobbing perceptions of high school teachers. Procedia-Social and Behavioral Sciences, 9, 1617-1623.

Dangaç, G., 2007. “Örgütlerde psikolojik yıldırma (mobbing) ve bir araştırma", Yüksek Lisans Tezi, Balıkesir Üniversitesi Sosyal Bilimler Enstitüsü, Balıkesir.

Dilman, T., 2007. "Özel hastanelerde çalışan hemşirelerin duygusal tacize maruz kalma durumlarının belirlenmesi”, Yüksek Lisans Tezi, Marmara Üniversitesi Sağlık Bilimleri Enstitüsü, İstanbul.

Doğan, M. A., 2009. "İlköğretim okullarında öğretmenlere uygulanan psikolojik şiddetin (mobbing) iş doyumuna etkisi: Ankara ili sincan ilçesi örneği”, Yüksek Lisans Tezi, Atılım Üniversitesi Sosyal Bilimler Enstitüsü, Ankara.

Ekiz, V., 2010. "İşletmelerde yaşanan psikolojik şiddet”, Yüksek Lisans Tezi, Atılım Üniversitesi Sosyal Bilimler Enstitüsü, Ankara. 
Ertek, Ş. S., 2009. "Yıldırma ve yıldırma mağduru öğretmenler üzerine bir araştırma", Yüksek Lisans Tezi, Beykent Üniversitesi Sosyal Bilimler Enstitüsü, İstanbul.

Ertürk, A., Cemaloğlu, N., 2014. Causes of mobbing behavior. Procedia-Social and Behavioral Sciences, 116, 3669-3678

Eser, O., 2008. Mobbing Kavramının Türkçe Serüveni. İstanbul Kültür Üniversitesi.

http://turkoloji.cu.edu.tr/YENI\%20TURK \%20DILI/oktay_eser_mobbing_kavrami.p df. Son Erişim tarihi: 09.11.2018.

Genç, O., Erdiş, E., 2015. Problematical of Mobbing in Construction Industry. Çukurova University Journal of the Faculty of Engineering and Architecture, 30(1), pp. 215-221.

Gökçe T. A., 2006. "İşyerinde yıldırma: özel ve resmi ilköğretim okulu öğretmen ve yöneticileri üzerinde yapılan bir araştırma", Doktora Tezi, Ankara Üniversitesi Eğitim Bilimleri Enstitüsü, Ankara.

Gülşen, C., Kılıç, M.A., 2014. Perceptıon of pre-school teachers to mobbing in terms of psycho-violence. Procedia-Social and Behavioral Sciences, 114. 446-451.

Heinemann, P., 1972. Mobbing-group violence by children and adults. Natur and Kultur, Stockholm.

Karavardar, G., 2010. Psikolojik Yıldırma ile Bazı Kişilik Özellikleri Arasındaki İlişki, Journal of New World Sciences Academy, 5, 3, 212-233.

Kaya, G., Ahi, B., Tabak, H. 2012. Primary education teachers' problem: mobbing (Kastamonu province sample). ProcediaSocial and Behavioral Sciences, 46, 838842.

Kocaman, F., 2017. Relationship between the mobbing perceptions and anger and the degree of anger locution of employees: a research on the doctors. Master Thesis, Süleyman Demirel University.

Leymann, H., 1990. Mobbing and psychological terror at workplaces, Springer Publishing Company, pp. 119126(8).

Leymann, H., 1996. The Content and Development of Mobbing at Work, European Journal of Work and Organizational Psychology, 5, 2, 165-184.

Mete, A.Y., 2013. Yüksek Öğretim Kurumlarında Psikolojik Yıldırma (Terör): Uygulayanlar, Mağdurlar ve Seyirciler. International Journal of Social Science, 6, 2, 977-993.

Serinkan, C., Akşit, İ.,Avcik, C., Arat, G., 2013. The study of students' perceptions of mobbing at Pamukkale University. Procedia-Social and Behavioral Sciences, 89, 856-861.

Solakoğlu, İ., 2007. "İşletmelerde mobbingin örgütsel kültüre etkisi ve bir sağlık kuruluşunda uygulama", Yüksek Lisans Tezi, Dumlupınar Üniversitesi Sosyal Bilimler Enstitüsü, Kütahya.

Şenerkal, R.,2014. "Üniversitelerde akademik personele yönelik mobbing süreci: mobbing davranışları ile akademisyenlerin sağlığı ve bireysel performansı ilişkisi”, Yüksek Lisans Tezi, Eskişehir Osmangazi Üniversitesi Sosyal Bilimler Enstitüsü, Eskişehir.

Tavşancıl, E. (2002). Tutumların ölçülmesi ve SPSS ile veri analizi. Nobel Yayıncılık, Ankara.

Tutumlu, M. V., 2017. "İşs yerlerinde psikolojik taciz (mobbing) algısı ve bir araştırma", Yüksek Lisans Tezi, Toros Üniversitesi Sosyal Bilimler Enstitüsü, Mersin. 
Türkeli, H., 2015. "Mobbing ve mobbingin örgütsel bağlılığa etkisi”, Yüksek Lisans Tezi, Beykent Üniversitesi Sosyal Bilimler Enstitüsü, İstanbul.

Yavuz, H., 2007. "Çalışanlarda mobbing (psikolojik şiddet) algısını etkileyen faktörler: sdü tıp fakültesi üzerine bir araştırma", Yüksek Lisans Tezi, Süleyman Demirel Üniversitesi Sosyal Bilimler Enstitüsü, Isparta.

Yıldırım, H., Uysaloğlu, B., 2012. Impact of demographic factors on employee's perception of mobbing: a case study from a logistics company. Procedia-Social and Behavioral Sciences, 58, 634-644.

Yüksel, N.E., 2015. The perception of mobbing in the top and middle level managers. Master Thesis, Kocaeli University. 